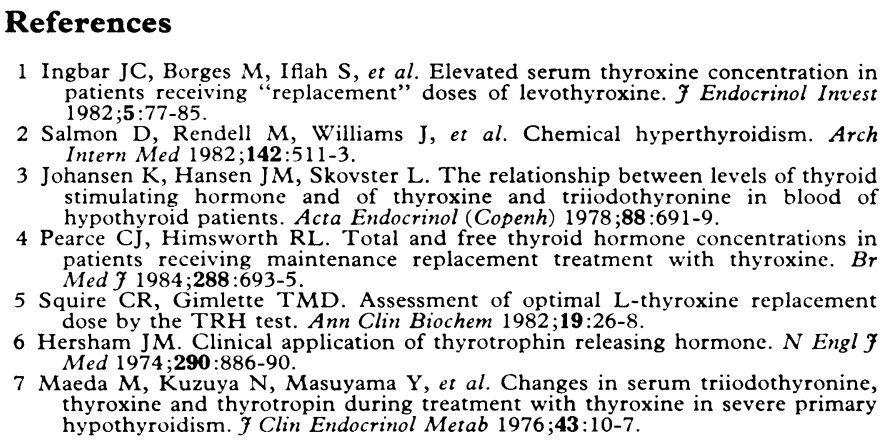

1 Ingbar JC, Borges $M$, Iflah S, et al. Elevated serum thyroxine concentration in patients receiving "replacement" doses of levothyroxine. $\mathcal{F}$ Endocrinol Inves $1982 ; 5 ; 77-85$.

2 Salmon D, Rendell M, Williams J, et al. Chemical hyperthyroidism. Arch Intern Med 1982;142:511-3.

3 Johansen K, Hansen JM, Skovster L. The relationship between levels of thyroid stimulating hormone and of thyroxine and triiodothyronine in blood of hypothyroid patients. Acta Endocrinol (Copenh) 1978;88:691-9. earce CJ, Himsworth RL. Total and free thyroid hormone concentrations in patients receiving maint $1984 ; \mathbf{2 8 8}: 693-5$
Med

5 Squire CR, Gimlette TMD. Assessment of optimal L-thyroxine replacement dose by the TRH test. Ann Clin Biochem 1982;19:26-8. Hersham JM. Clinical application of thyrotrophin releasing hormone. $N$ Engl f
Med 1974;290:886-90.

7 Maeda M, Kuzuya N, Masuyama Y, et al. Changes in serum triiodothyronine, thyroxine and thyrotropin during treatment with thyroxine in severe primary
hypothyroidism. $\mathcal{F}$ Clin Endocrinol Metab $1976 ; 43: 10-7$.

8 Plotnick GD, Vassar DL, Parisi AF, Hamilton BP, Carliner NH, Fisher HL. Systolic time intervals in hypothyroidism; end organ function as a reflection of clinical status. $A m \mathcal{F} M e d ~ S c i$ 1978;277:263-8.

9 O'Malley BP, Jennings PE, Cook N, Barnett DB, Rosenthal FD. The role of $5-\mathrm{HT}$ in the control of TSH and prolactin release in euthyroid subjects as and and zime

10 Northover B, O'Malley BP, Rosenthal FD. Alterations in systolic time intervals in primary hypothyroidism as a consequence of warming. 7 Clin Endocrinol Metab 1983;56:185-8.

11 Pittman CS, Chambers JB, Read VH. The extrathyroidal conversion rate of thyroxine to triiodothyronine in normal man. $\mathcal{F}$ Clin Invest 1971 ;50:1187-96.

12 Soppi E, Irjala K, Kaihola H-L, Viikari J. Acute effect of exogenous thyroxin dose on serum thyroxine and thyrotrophin levels in treated hypothyroid patients. Scand $\mathcal{F}$ Clin L.ab Invest 1984;44:353-6.

(Accepted 2 October 1984)

\title{
Successful plasma exchange in type 1 leprosy reversal reaction
}

\author{
F LUCHT, G RIFLE, H PORTIER, J M CHALOPIN, J BONHOMME
}

\begin{abstract}
A 24 year old man admitted to hospital with borderline lepromatous leprosy was treated with rifampicin, dapsone, and clofazimine. After four months he developed a reversal reaction and the diagnosis was modified to borderline tuberculoid leprosy. The dose of clofazimine was raised and prednisolone added to the regimen without any symptomatic response. His condition improved dramatically after five plasma exchanges on five successive days.
\end{abstract}

\section{Introduction}

The clinical features of leprosy may alter as the patient's immune response to the disease alters. An increase in immunity -termed reversal-is common after treatment, and the disease moves towards the tuberculoid pole. In the type 1 leprosy reversal reaction severe nerve lesions may occur ${ }^{1}$ and are usually controlled by clofazimine and steroids. The failure of this combination in one patient led us to try plasma exchanges.

\section{Case report}

A 24 year old black Senegalese man was first admitted in September 1983 with multiple hypoaesthetic bilateral, symmetrical hypopigmented macules on the neck, face, back, arms, and thighs and nodules on the earlobes. He was found to have symmetrical lesions of the upper branches of the facial, external popliteal, and ulnar nerves and enlargement of the left great auricular nerve. A scraping of the nasal mucosa showed numerous acid fast bacilli. Histopathological examination of an arm lesion showed, below a subepidermal

\footnotetext{
Hôpital du Bocage, Centre Hospitalier et Universitaire, Dijon, France

F LUCHT, MD, assistant, department of infectious and tropical diseases G RIFLE, MD, professor, department of nephrology

H PORTIER, MD, professor, department of infectious and tropical diseases J M CHALOPIN, MD, professor, department of nephrology

J BONHOMME, MD, professor, department of haematology

Correspondence to: Dr F Lucht, Service des Maladies Infectieuses et Tropicales, Hôpital d'Enfants, $10 \mathrm{Bd}$ Marechal-De-Lattre-de-Tassigny,
} BP 1542, 21034 Dijon Cedex, France. clear zone, a focalised granuloma made up of globular and vacuolated histiocytes loaded with viable acid fast bacilli (Ziehl-Neelsen's method) in all the layers of the dermis. Lymphoplasmocytes were sparse. Borderline lepromatous leprosy (Ridley-Jopling classification) was diagnosed.

After four months' treatment with rifampicin $600 \mathrm{mg}$, dapsone $100 \mathrm{mg}$, and clofazimine $100 \mathrm{mg}$ daily he developed increasing oedema, erythema, pain in the pre-existing lesions, and swelling of the affected nerves with diminution of their motor function. Temperature was $38.5^{\circ} \mathrm{C}$. A scraping of the nasal mucosa yielded negative results. Circulating immune complexes were absent. A type 1 leprosy reversal reaction was confirmed by skin biopsy: histopathological examination of a thigh lesion showed a focalised histiocytic granuloma in the middle and deep layers of the dermis, with in the upper layers epithelioid cells, sometimes organised in follicles. Viable acid fast bacilli were less numerous. Borderline tuberculoid leprosy was diagnosed.

On 7 January 1984 the dosage of clofazimine was increased to $400 \mathrm{mg}$ daily and prednisolone $1 \mathrm{mg} / \mathrm{kg}$ was introduced; dosages of rifampicin and dapsone remained as before. His condition did not improve, and the lesions remained painful. From 25 January, on five successive days, he was given five plasma exchanges. At each procedure $150 \%$ of theoretical plasma volume was exchanged for diluted albumin. On the third day his temperature was normal, and by the sixth day the oedema had resolved and the pain disappeared. Nerve paralysis was only slightly improved. Despite antibiotics, clofazimine, and steroids, which were continued in unaltered dosage until $10 \mathrm{March}$, on 17 February he developed a second, identical type 1 leprosy reversal reaction. Plasma exchange as before had a similar effect, after which his condition continued to improve.

\section{Discussion}

Plasma exchange has been used successfully in type 2 reactions (erythema nodosum leprosum) resulting from deposition of immune complexes, ${ }^{2}$ but to our knowledge it has never been used in type 1 reactions. Although results in a single case must be interpreted carefully, such a close relation between plasma exchange and clinical improvement suggests a causal relation.

Usually type 1 leprosy reversal reactions are controlled by clofazimine and steroids. The failure of these drugs in this case may have been due to the fact that rifampicin and dapsone were given in high dosages for a long period. In type 1 leprosy reversal reactions there is an increased phytohaemagglutinin lymphocyte response, which might be explained by a decrease in mycobacterial load in macrophages due to effective antileprosy 


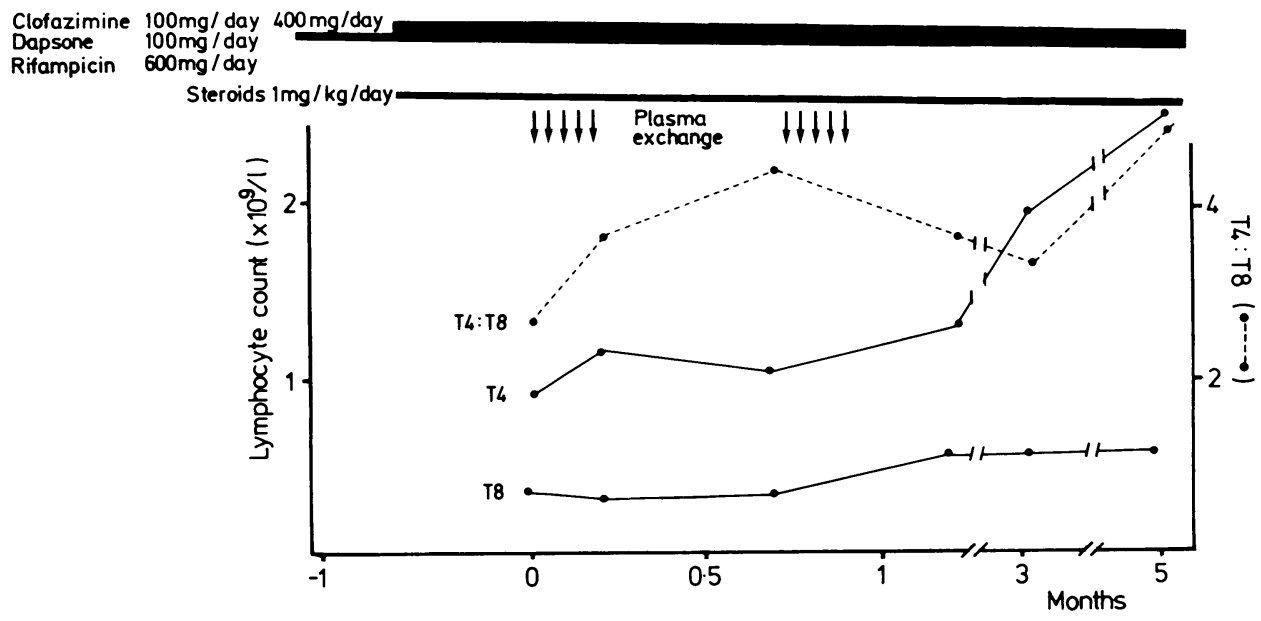

Numbers of T4 and T8 cells throughout treatment.

treatment ${ }^{3}$ or by the presence in the plasma of such patients of a factor augmenting the lymphocytic response to phytohaemagglutinin in vitro. ${ }^{4}$ The removal of such a factor might explain, at least in part, the beneficial effect of plasma exchange and the observed variations in numbers of T4 cells and in the ratio of T4 to T8 cells (figure). Why the first increase in the ratio of T4 to T8 cells was followed by a type 1 leprosy reversal reaction and the second was not remains unclear.

This observation may serve as an alternative explanation for the possible effect of plasma exchange on cell mediated immunity to the one previously suggested. ${ }^{5}$

\section{References}

1 Bjune G, Barnetson RStC. Plasma factors in delayed-type hypersensitivity. Clin Exp Immunol 1976;26:397-402.

2 Wallach D, Bussel A, Sansonetti P, et al. Echanges plasmatiques dans le traitement des lèpres lépromateuses. Acta Leprol (Geneve) 1979;76-7:285-90.

3 Kiprov DD. Influence of plasmapheresis on cellular immunity. Plasma separation and plasma fractionation. Basle: Karger, 1983:48-63.

4 Chalopin JM, Rifle G, Turc JM, Cortet P, Severac M. Immunological findings during successful treatment of $\mathrm{HBsAg}$ associated polyarteritis nodosa by plasmapheresis alone. Br Med $\mathcal{f} 1980 ; 280: 368$

5 Rook GAW. The potentiating, mitogenic and inhibitory effect on lymphocytes in vitro of macrophages in the lymph nodes of mice overloaded with myco-
bacterial products. Clin Exp Immunol 1975;21:63-7.

(Accepted 31 August 1984)

\section{ONE HUNDRED YEARS AGO}

The sudden appearance of cold weather has, apparently, had a favourable influence on the cholera-germ. The epidemic has rapidly diminished. It is difficult to arrive at an accurate estimate of cases and deaths, owing to discrepancies in statistics. According to the Prefect of the Seine, from November 7 th to November 13th, there were 464 deaths; the Bulletin de Statistique Municipal states them to be 385. Dr. Bertillon affirms that the cholera-mortality was the highest from November 7 th to 13 th. From November 5 th to 11 th, the proportion was 1 per 10,000 . In the military barracks, all diarrhoea-cases are removed to the hospitals, where patients are placed in different wards, according to the gravity of their condition. Formerly diarrhoea-cases were treated in the military infirmaries, but since the appearance of the epidemic, it has been decreed that they are to be removed; also, that ambulance-carriages belonging to the transport-service, recently organised, are to replace the military carriages for removing cholerapatients from the barracks. Disinfection is rigorously carried on in barracks. The drinking-water is boiled and filtered; extra rations of wine, rum, and tea, are distributed within the walls of the barracks. Ministerial decree increases the soldier's pay by a penny a day. The army-surgeons have such a keen sense of military discipline that they refuse to furnish any statistics concerning the epidemic to lay authorities. The medical men of the 14th Arrondissement have recently made an arrangement by which two of them are always in attendance at the Mayor's quarters day and night. M. WaldeckRousseau, Minister of the Interior, the Prefect of the Seine, and the Prefect of Police, visited the cholera-patients under treatment at the Tenon and Saint Louis Hospitals. Room has been provided for 2,000 patients at the different hospitals. The Minister directed that information concerning the patient's position should be inscribed on every bed-card, in order to ascertain particulars concerning those who had suffered indirectly from the epidemic, and required assistance. All public carriages and cabs that have been requisitioned by Government to convey cholera-patients will be bought by the city. The Syndical Chamber for hiring carriages and cabs issue strict orders to drivers of public carriages and cabs, that they are not to convey cholera-patients except under a police-order. The Société Générale des Télephones has received permission from the authorities, to afford gratuitous telephonic communication to all engaged in assisting cholera-cases. The Belgian Red Cross Society sends 500 francs for the sufferers from cholera. The Hospital of St. Jacques has publicly announced that it will receive any cholera-patient who desires to be treated homoeopathically. This hospital is admitted to be in an excellent sanitary condition. During the epidemic in Egypt, the Society for the Propagation of Cremation asked leave of the Prefect of Police to organise in Paris temporary cremation-apparatuses. This request has been rejected. The Russian Ambassador announces that travellers from Paris and all other infected localities will be detained on the frontier twenty-one days, their journey included. Four of the crew of the ironclad Admiral Duperre, in the Port of Toulon, have been seized with cholera; one has since died. A few cases have also been announced in that city. (British Medical fournal 1884.)

The people of Germany are thrifty as industrious, and they will be glad to be encouraged by a law compelling them to insure a premium for sickness and death. This is how the advantages of the new system, which comes into force on the 1st proximo [November], have been summarised. "The benefits to be derived by the sick or disabled workman are gratuitous medical attendances, medicines and appliances, and, after the third day, a money-allowance equal to half the daily wages, so long as it does not exceed seventy-five cents a day, for thirteen weeks. In case of death, a burial-allowance will be made, amounting to twenty times the daily average wage of the locality." We do not quite comprehend the last provision; but that is a small matter. The broad fact that insurance is henceforth to be compulsory in Germany is intelligible enough, and it is a fact well worth noting. If something of the sort could be devised and applied in England, much good would result. About thirty years ago, if we remember aright, the late Charles Dickens propounded a scheme of mutual help by insurance, by which the public might be provided with adequate help in sickness, and all the doctors would be well paid for their services. Something needs to be done in this sense on a large scale, for provident dispensaries are, beyond question, open to great abuses; and already there are not wanting signs that the system, new as it is, may yet wither from neglect while in the bud. (British Medical fournal 1884 ;ii:974.) 